\title{
Synthesis, Structure, and Properties of Polyacetylenes Possessing Chiral Spirobifluorene Moieties in the Side Chain
}

\author{
By Toshikazu TAKATA, ${ }^{*}$ Fumitaka ISHIWARI, Takashi SATO, Ryota SETO, and Yasuhito KoYAMA
}

Synthesis, property, and structure of a few polyacetylenes having the pendent optically active spirobifluorene moiety as a $C_{2}$ chiral group are described. Optically inactive achiral monomer 2-ethynyl-9,9'-spirobifluorene was obtained from 2-bromo$9,9^{\prime}$-spirobifluorene, while optically active monomers $(R)-2^{\prime}$-ethynyl-9, $9^{\prime}$-spirobifluorene-2-ol and $(R)$-2-acyloxy-2'-ethynyl$9,9^{\prime}$-spirobifluorene were prepared from optically pure 2,2'-dihydroxy-9,9'-spirobifluorene. Polymerizations of these monomers were carried out by a rhodium catalyst system $\left([\mathrm{Rh}(\mathrm{nbd}) \mathrm{Cl}]_{2}\right.$-triethylamine) in THF at room temperature to give polyacetylenes with $M_{\mathrm{w}} c a .25000$ in moderate yields. The chemical and thermal properties of polymers were evaluated. The structural characteristics were studied by UV-vis, CD, and Raman spectra in addition to the specific optical rotation. The experimental results suggested the formation of optically active polymers which took the cis-transoidal main chain conformation, while the main chains had helical structures as simulated ( $P$-screwed 16-1 helix in the case of poly $(R)-\mathbf{1 - O H})$. The formation of one-handed helical polymers was caused by the introduction of a group with molecular chirality in the side chain.

KEY WORDS: Spirobifluorene / Polyacetylene / Optically Active Polymer / Helical Structure / Axial Asymmetry / Chiral / cis-

Transoidal /

Among synthetic or artificial helical polymers such as polymethacrylates, ${ }^{1}$ polychloral, ${ }^{2}$ polyisocyanides, ${ }^{3}$ polyisocyanates, ${ }^{4}$ and polysilanes, ${ }^{5}$ polyacetylenes are the typical class of easily accessible helical polymers of which one-handed screw sense can be generated by adding chiral groups in their side chains. ${ }^{6-10}$ The chiral pendant group involves optically active carboxylic acid, ${ }^{6}$ alcohol, ${ }^{7}$ amino acid, ${ }^{8}$ carbohydrate, ${ }^{9}$ terpene $^{10}$ and so on. Although the optically active groups with point chirality in the side chain have been employed as the pendant groups so far, those based on molecular chirality such as axially asymmetric group may also serve as chiral inducer into the main chain of polyacetylene. ${ }^{11}$ Meanwhile, we have reported that the introduction of axially chiral groups such as optically active binaphtyl, biphenyl, and spirobifluorene groups into the polymer main chains always causes the induction of one-handed helical chirality. ${ }^{12}$ These optically active polymers can be applied to asymmetric catalysis. ${ }^{13}$ To clarify the effect of axially chiral groups attached to the side chain of polyacetylene on the chirality of the main chain, we have studied polyacetylenes having optically active spirobifluorene moieties as one of the typical $C_{2}$ chiral units in the side chains. This paper describes the synthesis, structure, and properties of these polyacetylenes.

\section{EXPERIMENTAL}

\section{Materials and Methods}

Triethylamine (Wako Pure Chemical Industries, Ltd.) was dried over calcium hydride and distilled prior to use. Commercially available materials and solvents including 9,9'- spirobifluorene (BEPHARM), $\mathrm{Pd}\left[\left(\mathrm{PPh}_{3}\right) \mathrm{Cl}\right]_{2}$ (Aldrich), CuI (Wako Pure Chemical Industries, Ltd.) and $\mathrm{Rh}[(\mathrm{nbd}) \mathrm{Cl}]_{2}$ (Wako Pure Chemical Industries, Ltd.) were used without further purification.

${ }^{1} \mathrm{H}(400 \mathrm{MHz})$ and ${ }^{13} \mathrm{C}(100 \mathrm{MHz})$ NMR spectra were recorded on a JEOL GTX-400 spectrometer using $\mathrm{CDCl}_{3}$ as the solvent and tetramethylsilane as the internal standard. Purifications by repeated preparative gel permeation chromatography (GPC) were performed on a JAI Co., Ltd. LC-9204 system (JAIGEL-1H-40) with $\mathrm{CHCl}_{3}$ as the eluent. Molecular weight and its distribution were measured by gel permeation chromatography (GPC) on a JASCO Gulliver system equipped with two consecutive liner polystyrene gel columns (TOSOH TSKgel G2000H $\mathrm{HL}_{\mathrm{XL}}$ and $\mathrm{GMH}_{\mathrm{XL}}$ ) at $30^{\circ} \mathrm{C}$, eluted with $\mathrm{CHCl}_{3}$ at a flow rate of $0.085 \mathrm{~mL} / \mathrm{min}$, and calibrated using polystyrene standards. IR spectra were recorded on a JASCO FT/IR230 spectrometer. Thermogravimetry (TG) was performed on a Shimadzu TGA-50 instrument at a heating rate of $10^{\circ} \mathrm{C} / \mathrm{min}$ under $\mathrm{N}_{2}$ atmosphere (flow rate of $50 \mathrm{~mL} / \mathrm{min}$ ) to determine decomposition temperature $T_{\mathrm{d} 5}$ at which $5 \%$ weight loss was observed. Differential scanning calorimetry (DSC) was carried out using a Shimadzu DSC-60 instrument at a heating rate of $10{ }^{\circ} \mathrm{C} / \mathrm{min}$ under $\mathrm{N}_{2}$ atmosphere (flow rate of $50 \mathrm{~mL} / \mathrm{min}$ ) to determine glass transition temperature $T_{\mathrm{g}}$. Melting points were measured with a Stuart Scientific SMP3. UV-vis spectra ware taken on a JASCO V-550 UV/VIS spectrophotometer. CD spectra ware taken on a JASCO J-820 spectropolarimeter. Specific optical rotations were measured on a JASCO DIP1000 digital polarimeter in a $10 \mathrm{~cm}$ cuvette. The solution property of the polymer in a diluted THF solution was 
examined by a SEC-VISC-RALLS system (Viscotek). The conformational analyses of polymers were carried out by using CAChe version 6.1.12 for Windows. The elementary analyses and HR-MAS spectra ware taken by National University Corporation Tokyo Institute of technology Center for Advanced Materials Analysis on request.

2-Bromo-9,9-spirobifluorene [3]. ${ }^{14}$ To a mixture of 9,9-spirobifluorene $(2,5.43 \mathrm{~g}, 17.2 \mathrm{mmol})$ and $\mathrm{FeCl}_{3}(2.1 \mathrm{mg}, 0.128$ mmol) dissolved in $\mathrm{CH}_{2} \mathrm{Cl}_{2}(50 \mathrm{~mL})$ was added dropwise $\mathrm{Br}_{2}$ $(1.4 \mathrm{~mL}, 27.5 \mathrm{mmol})$ at room temperature, and the mixture was stirred for $8 \mathrm{~h}$ at room temperature. The reaction was stopped by adding $\mathrm{H}_{2} \mathrm{O}(50 \mathrm{~mL})$. After the extraction with $\mathrm{CH}_{2} \mathrm{Cl}_{2}$ $(\times 2)$, the combined organic layer was washed with sat. aq. $\mathrm{Na}_{2} \mathrm{~S}_{2} \mathrm{O}_{3}$, dried over anhydrous $\mathrm{MgSO}_{4}$ and concentrated in vacuo. The residue was purified by the repeated preparative gel permeation chromatography (GPC) to give 2-bromo-9,9-spirobifluorene $(3,4.06 \mathrm{~g}, 10.3 \mathrm{mmol}, 60 \%)$ as colorless solids; mp 180.0-181.6 ${ }^{\circ} \mathrm{C} ;{ }^{1} \mathrm{H} \mathrm{NMR}\left(400 \mathrm{MHz}, \mathrm{CDCl}_{3}\right) \delta 7.85-7.79$ $(\mathrm{m}, 3 \mathrm{H}), 7.70(\mathrm{~d}, 1 \mathrm{H}, J=8.0 \mathrm{~Hz}), 7.48(\mathrm{dd}, 1 \mathrm{H}, J=8.0 \mathrm{~Hz}$, $1.8 \mathrm{~Hz}$ ), 7.41-7.35 (m, 3H), 7.12 (ddd, 3H, $J=7.6,7.6,1.0$ $\mathrm{Hz}), 6.85(\mathrm{~d}, 1 \mathrm{H}, J=1.8 \mathrm{~Hz}), 6.73-6.70(\mathrm{~m}, 3 \mathrm{H}) \mathrm{ppm}$ : ${ }^{13} \mathrm{C}$ NMR $\left(100 \mathrm{MHz}, \mathrm{CDCl}_{3}\right) \delta 150.78,148.51,147.88$, $141.71,140.74,140.62,130.87,128.23,127.97,127.93$, $127.89,127.26,124.07,124.03,121.37,121.30,120.11$, 120.11, 120.03, 65.76 ppm: IR (KBr) 3061, 1598, 1444, $1403,1262,1158,1105,1058,1005,955,864,822,772$, $750,727,666,634,574,421 \mathrm{~cm}^{-1}$.

4-(9,9' -Spirobi[fluorene]-2-yl)-2-methylbut-3-yn-2-ol [4]. ${ }^{15}$ Bromide 3 (4.06 g, $10.3 \mathrm{mmol}), \mathrm{Pd}\left[\left(\mathrm{PPh}_{3}\right) \mathrm{Cl}\right]_{2} \quad(368 \mathrm{mg}, 0.515$ mmol, $5 \mathrm{~mol} \%)$, and $\mathrm{CuI}(51.5 \mathrm{mg}, 0.515 \mathrm{mmol}, 5 \mathrm{~mol} \%)$ were mixed in a flask and repeatedly evacuated and flushed with argon. To the mixture were added abs. DMF $(20 \mathrm{~mL})$ and abs. triethylamine $(5 \mathrm{~mL})$ by syringe. After stirring the mixture for $5 \mathrm{~min}$ at room temperature, trimethylsilylacetylene $(3 \mathrm{~mL}$, $35.7 \mathrm{mmol}$ ) was added by syringe and the resulting mixture was stirred for $2 \mathrm{~h}$ at $90^{\circ} \mathrm{C}$. After complete consumption of the starting material was checked by TLC, the reaction mixture was quenched with brine $(20 \mathrm{~mL})$, filtered through celite ${ }^{\circledR}$, and extracted with $\mathrm{CH}_{2} \mathrm{Cl}_{2}$. The combined organic layer was washed with water and brine, dried over anhydrous $\mathrm{MgSO}_{4}$, concentrated in vacuo, and the residue was subjected to the separation by column chromatography on silica gel with hexane/ethyl acetate $(1: 1, \mathrm{v} / \mathrm{v})$ as eluent. The pure product was obtained as white solids $(4,1.07 \mathrm{~g}, 2.68 \mathrm{mmol}, 26 \%)$; 165.2-167.1 ${ }^{\circ} \mathrm{C} ;{ }^{1} \mathrm{H}$ NMR $\left(\mathrm{CDCl}_{3}, 400 \mathrm{MHz}\right) \delta 7.86-7.81(\mathrm{~m}$, $3 \mathrm{H}), 7.77(\mathrm{~d}, 1 \mathrm{H}, J=8.0 \mathrm{~Hz}), 7.43(\mathrm{dd}, 1 \mathrm{H}, J=8.0,1.5 \mathrm{~Hz})$, $7.40-7.35(\mathrm{~m}, 3 \mathrm{H}), 7.11(\mathrm{dd}, 3 \mathrm{H}, J=7.6,7.6 \mathrm{~Hz}), 6.78(\mathrm{~d}, 1 \mathrm{H}$, $J=1.5 \mathrm{~Hz}), 6.74-6.71(\mathrm{~m}, 3 \mathrm{H}), 1.50(\mathrm{~s}, 1 \mathrm{H}) \mathrm{ppm}:{ }^{13} \mathrm{C} \mathrm{NMR}$ $\left(100 \mathrm{MHz}, \mathrm{CDCl}_{3}\right) \delta 149.00,148.76,148.17,141.86,141.74$, $141.00,131.39,128.26,127.86,127.30,124.06,121.73$, $120.66,120.06,119.84,93.92,82.38,77.22,65.70,65.51$, 31.38, 31.33 ppm. IR (KBr) 3386, 3060, 2979, 2871, 1603, 1448, 1415, 1360, 1282, 1226, 1169, 1051, 958, 889, 843, 751, 728, 667, 636, 620, 599, 489, 463, 442, $422 \mathrm{~cm}^{-1}$.

2-Ethynyl-9,9' -spirobifluorene. [1-H]. ${ }^{15,16} \mathrm{NaH}$ (60\% in oil, $500 \mathrm{mg}, 12.5 \mathrm{mmol}$ ) was placed in a dry glass flask, which was then evacuated on a vacuum line and flushed with argon. After this evacuation-flush procedure was repeated three times, a three-way stopcock was attached to the flask and dry THF $(10 \mathrm{~mL})$ was added with a syringe to the flask. A solution of 4 $(1.07 \mathrm{~g}, 2.68 \mathrm{mmol})$ in dry THF $(10 \mathrm{~mL})$ was added to the THF suspension of $\mathrm{NaH}$ and the resulting mixture was refluxed for $24 \mathrm{~h}$. The reaction mixture was quenched with $\mathrm{MeOH}(50 \mathrm{~mL})$ and extracted with $\mathrm{CHCl}_{3}$. The combined organic layer was washed with sat. brine, dried over anhydrous $\mathrm{MgSO}_{4}$, and the solvents were evaporated to dryness. The resulting product was further purified by column chromatography on silica gel with hexane/ethyl acetate $(9: 1, \mathrm{v} / \mathrm{v})$ as eluent. The pure product was obtained as a white and resinous amorphous (1-H, $621 \mathrm{mg}$, $1.83 \mathrm{mmol}, 68 \%$ ); mp $168.5-170.2^{\circ} \mathrm{C}$ (lit., ${ }^{16} 169-170{ }^{\circ} \mathrm{C}$ ); ${ }^{1} \mathrm{H} \mathrm{NMR}\left(\mathrm{CDCl}_{3}, 400 \mathrm{MHz}\right) \delta 7.85-7.78(\mathrm{~m}, 4 \mathrm{H}), 7.50(\mathrm{dd}$, $1 \mathrm{H}, J=7.8,1.5 \mathrm{~Hz}$ ), 7.37 (ddd, $1 \mathrm{H}, J=7.6,7.6,1.0 \mathrm{~Hz})$, 7.15-7.09 (m, 3H), $6.86(\mathrm{~d}, 1 \mathrm{H}, J=1.5 \mathrm{~Hz}), 6.75-6.70(\mathrm{~m}$, $3 \mathrm{H}), 2.95$ (s, $1 \mathrm{H}) \mathrm{ppm} ;{ }^{13} \mathrm{C} \mathrm{NMR}\left(\mathrm{CDCl}_{3}, 100 \mathrm{MHz}\right) \delta 149.11$, $148.85,148.04,142.40,141.76,140.89,131.93,128.41$, $127.82,127.72,124.13,124.03,121.04,120.35,120.07$, 119.98, 83.90, 77.29, 65.71 ppm; IR (KBr): 3282, 3062, 2102, 1461, 1447, 1414, 1264, 1154, 1105, 887, 833, 752, $731 \mathrm{~cm}^{-1}$. (R)-2,2' -Dihydroxy-9,9'-spirobifluorene [(R)-5]. Optically pure $2,2^{\prime}$-dihydroxy-9, $9^{\prime}$-spirobifluorene was obtained by the separation of a racemic mixture of $2,2^{\prime}$-dihydroxy-9, $9^{\prime}$-spirobifluorene ${ }^{17}$ with a preparative chiral column (Daicel CHIRALPAK ${ }^{\circledR}$ IA, eluent: $\mathrm{CHCl}_{3}-i-\mathrm{PrOH} 95 / 5 \mathrm{v} / \mathrm{v}$ ). First eluted isomer was $(S)-2,2^{\prime}$-dihydroxy-9, $9^{\prime}$-spirobifluorene $[(S)-5]$, while second one was $(R)-2,2^{\prime}$-dihydroxy-9, $9^{\prime}$-spirobifluorene $[(R)-5]$, in comparison with that obtained by the diastereomer method. ${ }^{18}$ Optically purity was evaluated by HPLC with a chiral column $\left(\mathrm{CHIRAL}\right.$ PAK $\left.{ }^{\circledR} \mathrm{AD}-\mathrm{H}\right)$ that the optical purity of $(R)-\mathbf{5}$ was over $99 \%$.

$(R)$-2-Hydroxy-2' -trifluoromethanesulfonyloxy-9,9' -spirobifluorene $[(\boldsymbol{R})-6]$. To a mixture of optical pure $(R)-5(633 \mathrm{mg}$, $1.82 \mathrm{mmol})$ and triethylamine $(0.8 \mathrm{~mL}, 5.7 \mathrm{mmol})$ dissolved in $\mathrm{CH}_{2} \mathrm{Cl}_{2}(75 \mathrm{~mL})$ was added dropwise trifluoromethanesulfonic anhydride $(1.8 \mathrm{~mL}, 6.4 \mathrm{mmol})$ dissolved in abs. $\mathrm{CH}_{2} \mathrm{Cl}_{2}$ $(25 \mathrm{~mL})$ over a period of $1-2 \mathrm{~h}$ at $-10^{\circ} \mathrm{C}$ and the reaction mixture was stirred for additional $1 \mathrm{~h}$ at $-10^{\circ} \mathrm{C}$. The resulting mixture was allowed to warm up to room temperature and stirred at this temperature for $10 \mathrm{~h}$, after which the reaction was quenched by water. The organic phase was separated with a separatory funnel, while the aqueous phase was extracted three times with $\mathrm{CH}_{2} \mathrm{Cl}_{2}$. The combined organic layer was washed with sat. aq. $\mathrm{NaHCO}_{3}$ and brine, dried over anhydrous $\mathrm{MgSO}_{4}$, and the solvents were evaporated to dryness. The collected product was further purified by column chromatography on silica gel with hexane/ethyl acetate $(5: 1, \mathrm{v} / \mathrm{v})$ as eluent. The pure product was obtained as a white and resinous amorphous $((R)-6,349 \mathrm{mg}, 40 \%)$; mp 77.6-79.9 ${ }^{\circ} \mathrm{C} ;[\alpha]_{\mathrm{D}}{ }^{21}+11.6(\mathrm{c} 0.39$, THF); ${ }^{1} \mathrm{H} \mathrm{NMR}\left(\mathrm{CDCl}_{3}, 400 \mathrm{MHz}\right) \delta 7.87(\mathrm{~d}, 1 \mathrm{H}, J=8.4 \mathrm{~Hz})$, $7.82(\mathrm{~d}, 1 \mathrm{H}, J=7.8 \mathrm{~Hz}), 7.76(\mathrm{~d}, 1 \mathrm{H}, J=7.6 \mathrm{~Hz}), 7.72$, (d, $1 \mathrm{H}, J=8.1 \mathrm{~Hz}), 7.40(\mathrm{ddd}, 1 \mathrm{H}, J=7.6,7.6,1.0 \mathrm{~Hz}), 7.36$ (ddd, $1 \mathrm{H}, J=7.6,7.6,1.0 \mathrm{~Hz}), 7.28(\mathrm{dd}, 1 \mathrm{H}, J=8.4,2.4 \mathrm{~Hz})$, 7.17 (ddd, $1 \mathrm{H}, J=7.6,7.6,1.0 \mathrm{~Hz}$ ), 7.06 (ddd, $1 \mathrm{H}, J=7.6$, 
7.6, $1.0 \mathrm{~Hz}), 6.87$ (dd, 1H, $J=8.4,2.4 \mathrm{~Hz}), 6.77,(\mathrm{~d}, 1 \mathrm{H}, J=$ $7.6 \mathrm{~Hz}), 6.67(\mathrm{~d}, 1 \mathrm{H}, J=7.8 \mathrm{~Hz}), 6.63(\mathrm{~d}, 1 \mathrm{H}, J=2.4 \mathrm{~Hz})$, $6.17(\mathrm{~d}, 1 \mathrm{H}, J=2.4 \mathrm{~Hz}) \mathrm{ppm} ;{ }^{13} \mathrm{C} \mathrm{NMR}\left(\mathrm{CDCl}_{3}, 100 \mathrm{MHz}\right)$ $\delta 155.77,151.23,149.42,149.20,148.90,146.72,141.90$, $141.64,139.66,134.75,130.49,128.71,128.22,128.13$, $126.96,124.26,121.28,121.04,120.19,117.48\left(\mathrm{q}, J_{\mathrm{C}-\mathrm{F}}=\right.$ $195 \mathrm{~Hz}), 117.48,117.00,111.99,65.76 \mathrm{ppm}$; IR (KBr) 3546, 3063, 2091, 1612, 1450, 1420, 1290, 1213, 979, 964, 889, 858, 838, 797, 757, 735, 608, 580, 519, $433 \mathrm{~cm}^{-1}$; FAB HR-MS Calcd for $\mathrm{C}_{26} \mathrm{H}_{15} \mathrm{~F}_{3} \mathrm{O}_{4} \mathrm{~S}$ : 480.0643 . Found: 480.0643 .

(R)-2-Hydroxy-2' -(trimethylsilyl)ethynyl-9,9' -spirobifluorene [(R)-7]. Monotriflate $(R)-6$ (349 mg, $0.35 \mathrm{mmol}), \mathrm{Pd}\left[\left(\mathrm{PPh}_{3}\right)\right.$ $\mathrm{Cl}]_{2}(25 \mathrm{mg}, 0.035 \mathrm{mmol}, 10 \mathrm{~mol} \%)$, and $\mathrm{CuI}(7 \mathrm{mg}, 0.035$ mmol, $10 \mathrm{~mol} \%$ ) were mixed and repeatedly evacuated and flushed with argon. To the mixture were added abs. DMF $(20 \mathrm{~mL})$ and abs. triethylamine $(1 \mathrm{~mL})$ by syringe. After stirring the mixture for $5 \mathrm{~min}$ at room temperature, trimethylsilylacetylene $(1 \mathrm{~mL}, 7.1 \mathrm{mmol})$ was added by syringe and the resulting mixture was stirred for $2 \mathrm{~h}$ at $90^{\circ} \mathrm{C}$. The complete consumption of the starting material was followed by the quenching with brine $(20 \mathrm{~mL})$, filteration through celite ${ }^{\circledR}$, and extraction with $\mathrm{CH}_{2} \mathrm{Cl}_{2}$. The combined organic layer was washed with water and brine, dried over anhydrous $\mathrm{MgSO}_{4}$, concentrated in vacuo, and the residue was subjected to the separation by column chromatography on silica gel with n-hexane/ethyl acetate $(5: 1, \mathrm{v} / \mathrm{v})$ as eluent. The pure product was obtained as white solids $(150 \mathrm{mg}, 48 \%)$; mp $165.2-167.1^{\circ} \mathrm{C} ;[\alpha]_{\mathrm{D}}{ }^{22}+80.6$ (c $0.54, \mathrm{THF}) ;{ }^{1} \mathrm{H} \mathrm{NMR}\left(\mathrm{CDCl}_{3}, 400 \mathrm{MHz}\right) \delta 7.82-7.69(\mathrm{~m}$, $4 \mathrm{H}), 7.49$ (dd, $1 \mathrm{H}, J=7.6,1.0 \mathrm{~Hz}), 7.37$ (ddd, $1 \mathrm{H}, J=7.6$, $7.6,1.0 \mathrm{~Hz}$ ), 7.34 (ddd, $1 \mathrm{H}, J=7.6,7.6,1.0 \mathrm{~Hz}$ ), 7.13 (ddd, $1 \mathrm{H}, J=7.6,7.6,1.0 \mathrm{~Hz}), 7.04(\mathrm{ddd}, 1 \mathrm{H}, J=7.6,7.6,1.0 \mathrm{~Hz})$, 6.86-6.84 (m, 1H), $6.75(\mathrm{~d}, 1 \mathrm{H}, J=7.6 \mathrm{~Hz}), 6.67(\mathrm{~d}, 1 \mathrm{H}$, $J=7.6 \mathrm{~Hz}), 6.15(\mathrm{~d}, 1 \mathrm{H}, J=2.2 \mathrm{~Hz}), 4.59(\mathrm{~s}, 1 \mathrm{H}), 0.16(\mathrm{~s}$, 9H) ppm; ${ }^{13} \mathrm{C} \mathrm{NMR}\left(100 \mathrm{MHz}, \mathrm{CDCl}_{3}\right) \delta 155.74,150.32$, $149.24,148.77,147.61,142.11,140.98,134.87,132.01$, $128.42,128.01,127.97,127.75,126.87,124.26,124.06$, $122.21,121.19,120.40,119.90,119.33,115.27,114.17$, 111.19, 105.39, 94.50, 0.00 ppm; IR (KBr) 3448, 3064, 2960, 2152, 1654, 1611, 1542, 1508, 1450, 1289, 1249, 856, 757, $735,640 \mathrm{~cm}^{-1}$; FAB HR-MS Calcd for $\mathrm{C}_{30} \mathrm{H}_{24} \mathrm{OSiNa}$ : 451.1494. Found: 451.1494.

(R)-2-Ethynyl-2' -hydroxy-9,9' -spirobifluorene [(R)-1-OH]. A mixture of $(R)-7(150 \mathrm{mg}, 0.349 \mathrm{mmol})$, potassium carbonate (105 mg, $0.757 \mathrm{mmol})$, and $\mathrm{THF} / \mathrm{MeOH}$ mixed solvent (1:1, $20 \mathrm{~mL}$ ) was stirred for $3 \mathrm{~h}$ at room temperature. The reaction mixture was diluted with $\mathrm{CH}_{2} \mathrm{Cl}_{2}(40 \mathrm{~mL})$, washed with water, dried over anhydrous $\mathrm{MgSO}_{4}$, and concentrated in vacuo. The resulting residue was subjected to the separation by column chromatography on silica gel with hexane/ethyl acetate $(5: 1$, $\mathrm{v} / \mathrm{v}$ ) as eluent, yielding pure product as white solids (112 mg, 90\%); mp 93.4-94.8 ${ }^{\circ} \mathrm{C} ;[\alpha]_{\mathrm{D}}{ }^{22}+67.6$ (c 0.13 , THF); ${ }^{1} \mathrm{H}$ NMR $\left(\mathrm{CDCl}_{3}, 400 \mathrm{MHz}\right) \delta 7.82(\mathrm{~d}, 1 \mathrm{H}, J=7.8 \mathrm{~Hz}), 7.77(\mathrm{~d}, 1 \mathrm{H}, J=$ $7.8 \mathrm{~Hz}), 7.73(\mathrm{~d}, 1 \mathrm{H}, J=7.6 \mathrm{~Hz}), 7.69(\mathrm{~d}, 1 \mathrm{H}, J=8.3 \mathrm{~Hz})$, $7.50(\mathrm{dd}, 1 \mathrm{H}, J=7.6,1.2 \mathrm{~Hz}), 7.37(\mathrm{ddd}, 1 \mathrm{H}, J=7.6,7.6$, $1.0 \mathrm{~Hz}$ ), 7.33 (ddd, $1 \mathrm{H}, J=7.6,7.6,1.0 \mathrm{~Hz}), 7.13(\mathrm{ddd}, 1 \mathrm{H}$, $J=7.6,7.6,1.0 \mathrm{~Hz}$ ), 7.04 (ddd, $1 \mathrm{H}, J=7.6,7.6,1.0 \mathrm{~Hz}), 6.88$ $(\mathrm{d}, 1 \mathrm{H}, J=1.0 \mathrm{~Hz}), 6.84(\mathrm{dd}, 1 \mathrm{H}, J=8.2,2.4 \mathrm{~Hz}), 6.76(\mathrm{~d}$, $1 \mathrm{H}, J=7.6 \mathrm{~Hz}), 6.67(\mathrm{~d}, 1 \mathrm{H}, J=7.6 \mathrm{~Hz}), 6.15(\mathrm{~d}, 1 \mathrm{H}$, $J=2.4 \mathrm{~Hz}) \mathrm{ppm} ;{ }^{13} \mathrm{C} \mathrm{NMR}\left(100 \mathrm{MHz}, \mathrm{CDCl}_{3}\right) \delta 155.98$, $150.14,149.13,147.45,142.28,141.67,140.80,131.96$, $128.42,127.93,127.89,127.86,127.77,124.19,123.89$, $123.86,121.09,121.08,120.65,120.33,119.86,119.22$, $115.21,115.19,111.04,83.86,65.89$ ppm; IR (KBr) 3630, $3282,1586,1490,1450,1414,1386,1290,1267,1209,1106$, 1026, 867, 837, 789, 769, 757, 733, 664, 602, 589, $541 \mathrm{~cm}^{-1}$; FAB HR-MS Calcd for $\mathrm{C}_{27} \mathrm{H}_{16} \mathrm{O}$ : 356.1201. Found: 356.1201; Anal. Calcd for $\mathrm{C}_{27} \mathrm{H}_{16} \mathrm{O} \cdot 1 / 2 \mathrm{H}_{2} \mathrm{O}, \mathrm{C} 88.74, \mathrm{H} 4.69$. Found $\mathrm{C}$ 88.74, H 4.93 .

(R)-2-Acyloxy-2' -ethynyl-9,9' -spirobifluorene [(R)-1-OAc]. To a mixture of $(R)-\mathbf{1 - O H}(100 \mathrm{mg}, 0.28 \mathrm{~mol})$ and $\mathrm{Et}_{3} \mathrm{~N}(2 \mathrm{~mL}$, $14 \mathrm{mmol})$ in $\mathrm{CH}_{2} \mathrm{Cl}_{2}(10 \mathrm{~mL})$ was added dropwise acetylchloride $(1 \mathrm{~mL}, 13 \mathrm{mmol})$ over a period of $1-2 \mathrm{~min}$ at $0{ }^{\circ} \mathrm{C}$. The mixture was stirred for $30 \mathrm{~min}$ and then quenched by adding water $(20 \mathrm{~mL})$. The organic layer was separated and the aqueous phase was extracted three times with $\mathrm{CH}_{2} \mathrm{Cl}_{2}$. The combined organic layer was washed with sat. aq. $\mathrm{NaHCO}_{3}$ and brine, dried over anhydrous $\mathrm{MgSO}_{4}$ and evaporated to dryness. The resulting product was further purified by column chromatography on silica gel with hexane/ethyl acetate $(9: 1, \mathrm{v} / \mathrm{v})$ as eluent. The pure product was obtained as a white and resinous amorphous $(100 \mathrm{mg}, 90 \%)$; mp $93.8-94.8^{\circ} \mathrm{C} ;[\alpha]_{\mathrm{D}}{ }^{22}+4.3(\mathrm{c}$ $0.11, \mathrm{THF}) ;{ }^{1} \mathrm{H} \mathrm{NMR}\left(400 \mathrm{MHz}, \mathrm{CDCl}_{3}\right) \delta$ 7.84-7.76 (m, 4H), 7.50 (dd, $1 \mathrm{H}, J=8.4,1.4 \mathrm{~Hz}$ ), 7.37 (ddd, 1H, $J=7.6,7.6$, $1.0 \mathrm{~Hz}), 7.37(\mathrm{ddd}, 1 \mathrm{H}, J=7.6,7.6,1.0 \mathrm{~Hz}), 7.15-7.08(\mathrm{~m}$, $3 \mathrm{H}), 6.87(\mathrm{dd}, 1 \mathrm{H}, J=1.5,0.8 \mathrm{~Hz}), 6.76(\mathrm{ddd}, 1 \mathrm{H}, J=7.6$, $0.8,0.8 \mathrm{~Hz}), 6.70$ (ddd, $1 \mathrm{H}, J=7.6,0.8,0.8 \mathrm{~Hz}), 6.44(\mathrm{dd}, 1 \mathrm{H}$, $J=1.5,0.8 \mathrm{~Hz}), 2.97(\mathrm{~s}, 1 \mathrm{H}), 2.16(\mathrm{~s}, 3 \mathrm{H}) \mathrm{ppm} ;{ }^{13} \mathrm{C} \mathrm{NMR}$ $\left(100 \mathrm{MHz}, \mathrm{CDCl}_{3}\right) \delta 169.25,150.44,149.52,148.53,148.30$, $148.18,142.32,140.93,140.83,139.42,132.09,128.55$, $128.06,128.02,127.86,127.81,124.26,124.03,121.48$, $121.20,120.58,120.35,119.99,119.91,117.31,83.79,77.44$, 65.64, 21.03 ppm; IR (KBr): 3285, 1753, 1655, 1560, 1542, 1508, 1450, 1368, 1262, 1208, 912, 836, 771, 758, $598 \mathrm{~cm}^{-1}$; FAB HR-MS Calcd for $\mathrm{C}_{29} \mathrm{H}_{18} \mathrm{O}_{2}$ : 398.1307, Found: 398 . 1307; Anal. Calcd for $\mathrm{C}_{29} \mathrm{H}_{18} \mathrm{O}_{2} \cdot 1 / 3 \mathrm{H}_{2} \mathrm{O}, \mathrm{C} 86.12, \mathrm{H} 4.65$. Found C 86.14, H 4.82.

\section{Polymerization}

A Typical Procedure for 1-H. Monomer 1-H (50 mg, 0.15 mmol) was placed in a glass flask, which was then evacuated on a vacuum line and flushed with argon. After the evacuationflush procedure was repeated three times, a three-way stopcock was attached to the flask and dry THF $(0.19 \mathrm{~mL})$ was introduced by a syringe. To the mixture was added a solution

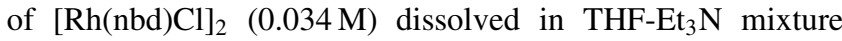
$(1.0: 2.3 \mathrm{v} / \mathrm{v}, 0.092 \mathrm{~mL})$ at room temperature. After stirring the mixture for $8 \mathrm{~h}$, the polymerization mixture was precipitated in $\mathrm{MeOH}$, the precipitates were collected by filtration, and the solid product was dried in vacuo at $80^{\circ} \mathrm{C}$ for $3 \mathrm{~h}$ to give poly1H (41 mg, 81\%). IR (KBr) 3061, 2959, 1446, 1260, 1093, 1024, $803,750,730,635,415 \mathrm{~cm}^{-1} \cdot{ }^{1} \mathrm{H}$ NMR spectrum of poly1-H was too broad to be assigned. 
poly $(R)$-1-OH: $72 \%$ yield. $[\alpha]_{\mathrm{D}}^{22}+217$ (c 0.11 , THF); IR (KBr): 3437, 2962, 1616, 1451, 1261, 1096, 1028, 803, 755, $473,418 \mathrm{~cm}^{-1}$.

poly $(R)$-1-OAc: $66 \%$ yield. $[\alpha]_{\mathrm{D}}{ }^{22}+157$ (c 0.085 , THF); IR (KBr) 3062, 1754, 1609, 1450, 1419, 1367, 1261, 1205, 1105, $1006,910,805,770,743,637,581,419 \mathrm{~cm}^{-1}$.

\section{RESULTS AND DISCUSSION}

\section{Synthesis of Monomers}

Ethynylspirobifluorene monomers 1, i.e., optically inactive

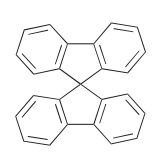

2

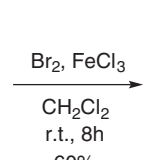

$60 \%$

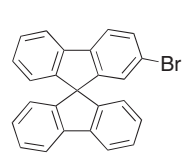

3

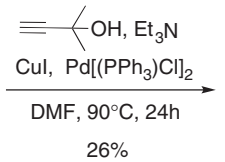

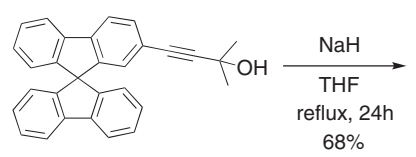

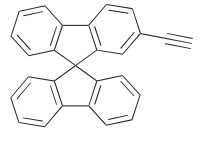

1-H
Scheme 1.
1-H, optically active $(R)-\mathbf{1 - O H}$, and optically active $(R)-\mathbf{1 -}$

OAc, were prepared according to Schemes 1 and 2. Commercially available $9,9^{\prime}$-spirobifluorene 2 was brominated in $60 \%$ yield with bromine in the presence of ferric chloride followed by the Sonogashira coupling with 2-hydroxy-2-methylbut-3yne to give protected ethynylspirobifluorene 4 in $26 \%$ yield. Treatment of $\mathbf{4}$ with sodium hydride in THF yielded 2-ethynyl$9,9^{\prime}$-spirobifluorene $\mathbf{1 - H}$ in $68 \%$ yield (Scheme 1). ${ }^{15,16}$

Optically pure 2,2'-dihydroxyspirobifluorene $(R)-5$ was obtained by the chiral column separation of its racemic mixture according to the reported method. ${ }^{17}$ According to Scheme 2, the monotriflation of $(R)-5$ with trifluoroacetic anhydride (40\% yield) followed by the Sonogashira coupling with trimetylsilylacetylene gave TMS-protected product 7 in $48 \%$ yield. The methanolysis of 7 with potassium carbonate to hydroxy monomer $(R)-\mathbf{1 - O H}(90 \%$ yield) was followed by acetylation with acetyl chloride afforded acetoxy monomer $(R)$-1-OAc in $90 \%$ yield.

The structures of these monomers were determined by IR, ${ }^{1} \mathrm{H}$ NMR, elemental analysis, and so on. ${ }^{1} \mathrm{H}$ NMR spectra of the monomers are shown in Figure 1. The distinct signals at $2.97\left(\mathrm{c}^{\prime}\right)$ and $2.16\left(\mathrm{c}^{\prime \prime}\right) \mathrm{ppm}$ in the spectrum of $(R)$-1-OAc corresponded to the protons of the acetylene and acetyl groups, respectively. Ortho-situated proton $\mathrm{d}^{\prime \prime}$ at the peri position and
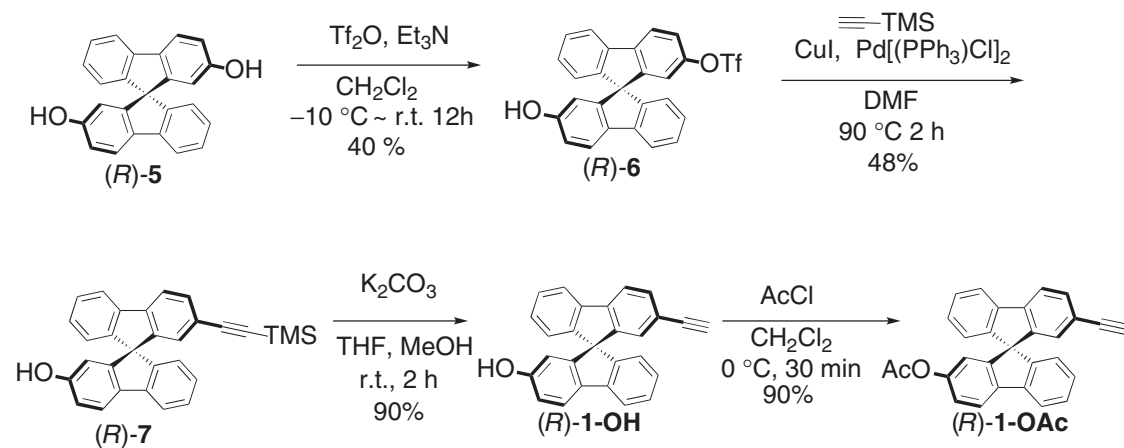

Scheme 2.

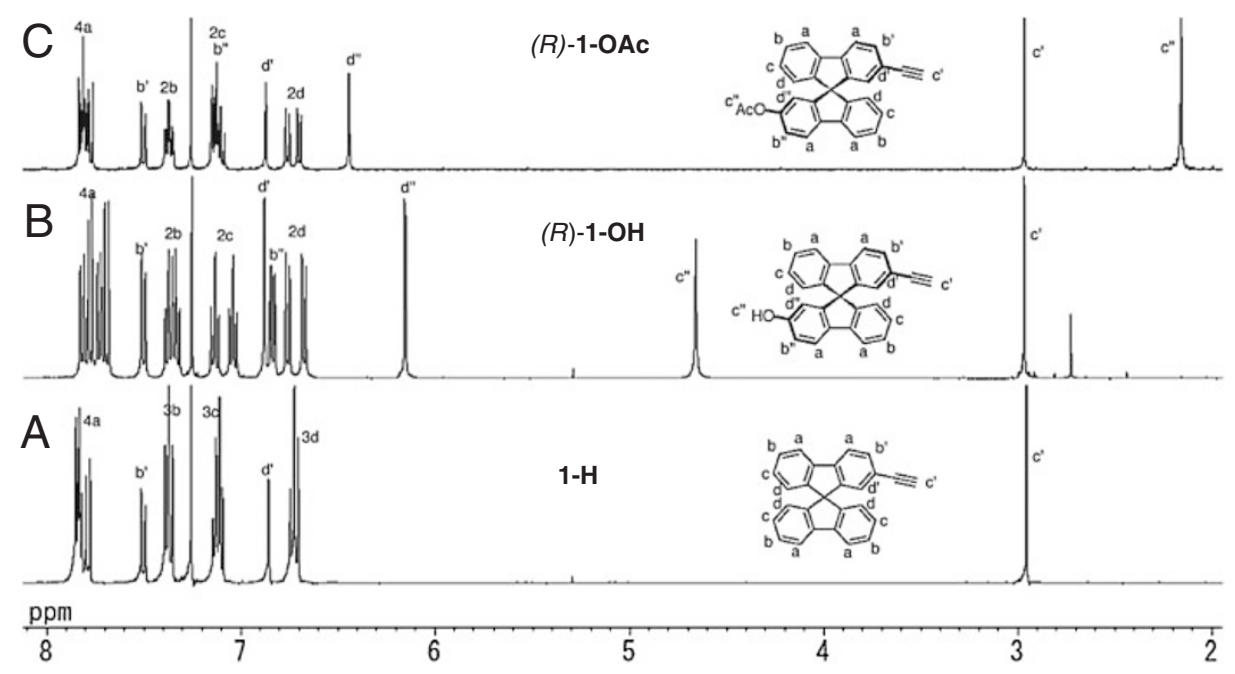

Figure 1. Partial ${ }^{1} \mathrm{H}$ NMR spectra of $(\mathbf{A}) \mathbf{1}-\mathrm{H},(\mathbf{B})(R)-\mathbf{1}-\mathrm{OH}$, and (C) $(R)-\mathbf{1 - O A c}\left(400 \mathrm{MHz}, \mathrm{CDCl}_{3}, 298 \mathrm{~K}\right)$. 
Table I. Polymerization of ethynyl spirobifluorenes 1

\begin{tabular}{|c|c|c|c|c|c|c|c|c|c|c|c|}
\hline \multirow{3}{*}{ Entry } & \multirow{3}{*}{ Solv. } & \multirow{3}{*}{ Time/h } & \multirow{3}{*}{ Product } & \multirow{3}{*}{ Yield ${ }^{\mathrm{a}} \%$} & \multicolumn{5}{|c|}{ Molecular Weight } & & \\
\hline & & & & & \multicolumn{2}{|c|}{$\mathrm{GPC}^{\mathrm{b}}$} & \multicolumn{3}{|c|}{$\mathrm{LS}^{\mathrm{c}}$} & \multicolumn{2}{|c|}{$[\alpha]_{D}^{d}$} \\
\hline & & & & & $M_{\mathrm{w}} \times 10^{-3}$ & PDI & $M_{\mathrm{w}} \times 10^{-3}$ & PDI & $\mathrm{a}$ & mononer & polymer \\
\hline 1 & toluene & 24 & poly1-H & 64 & 15.3 & 1.41 & & & & & \\
\hline 2 & $\mathrm{CHCl}_{3}$ & 24 & poly1-H & 76 & 14.3 & 1.38 & & & & & \\
\hline 3 & THF & 8 & poly1-H & 81 & 29.1 & 1.47 & 7560 & 1.41 & 0.85 & & \\
\hline 4 & toluene & 24 & $\operatorname{poly}(R)-1-\mathrm{OH}$ & 78 & 24.8 & 1.68 & & & & & \\
\hline 5 & THF & 24 & $\operatorname{poly}(R)-1-\mathrm{OH}$ & 74 & 22.5 & 1.49 & & & & & \\
\hline 6 & THF & 8 & poly $(R)-1-0 H$ & 70 & 24.9 & 2.06 & 1020 & 1.27 & 0.91 & +67.6 & +217 \\
\hline 7 & THF & 24 & $\operatorname{poly}(R)-1-O A c$ & 85 & 22.3 & 2.14 & & & & & \\
\hline 8 & THF & 8 & $\operatorname{poly}(R)$-1-OAc & 66 & 27.3 & 1.38 & 2140 & 1.34 & 0.88 & +43.2 & +157 \\
\hline
\end{tabular}

a) Isolated yield. b) Gel Permeation Chromatography (PSt Standards, Solvent: THF). c) Light Scattering (THF). d) Specific Rotation (THF, r.t., $c$ 0.13 for 1-OH, 0.11 for 1-OAc, 0.11 for poly $(R)-1-0 H$, and 0.085 poly $(R)-1-O A c)$ at $25^{\circ} \mathrm{C}$.

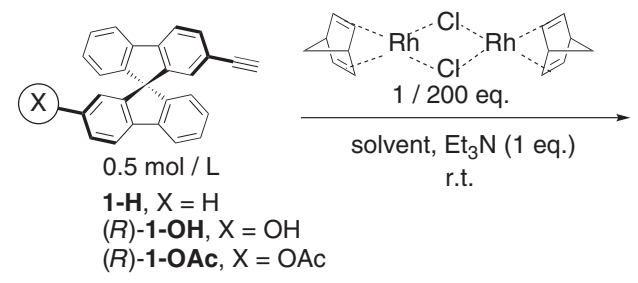

Scheme 3.

$\mathrm{OH}$ proton $\mathrm{c}^{\prime \prime}$ are also indicative of the structure of $(R)-\mathbf{1 - O H}$. Other aromatic protons signals were completely assigned as shown in Figure 1.

\section{Polymerization and Polymer Properties}

Since a typical polymerization catalyst for acetylene monomers, $[\mathrm{Rh}(\mathrm{ndb}) \mathrm{Cl}]_{2}$, is known to give polyacetylenes possessing cis-transoidal main chain conformation, ${ }^{19}$ we used $[\mathrm{Rh}(\mathrm{ndb}) \mathrm{Cl}]_{2}$-triethylamine (TEA) catalyst system for the present three monomers $\mathbf{1}$. The polymerization of 1-H, $(R)-\mathbf{1 -}$ OH, and $(R)$-1-OAc in THF ([C] $0.5 \mathrm{M})$ proceeded well according to Scheme 3 (at $25^{\circ} \mathrm{C}$, for $8 \mathrm{~h}$ ), independent of the presence of $\mathrm{OH}$ group, to afford the corresponding polyacetylenes poly1. The crude materials were purified by precipitating into methanol to give the corresponding polyacetylenes poly1$\mathbf{H}, \operatorname{poly}(R)-\mathbf{1 - O H}$, and poly $(R)-\mathbf{1 - O A c}$ as reddish solids.

The polymerization results are summarized in Table I. The yields of the polyacetylenes were 66-70\%, while the molecular weight $M_{\mathrm{w}}$ was around 27,000 by GPC in each case. Since the polymers had the bulky pendant groups which probably made polymers rigid rod-like, their molecular weights were also evaluated by a light scattering method. $M_{\mathrm{w}}$ of the polymers was estimated over 1,000,000, while polydispersity (PDI) was around 1.3 by the light-scattering measurement. The polymers showed high Mark-Houwink's $a$-value as $c a$. 0.9, suggesting that these polymers take a rod-like structure in solution state, as expected.

Thermal property of the polymers was evaluated by DSC and TGA. No glass transition point was observed for the polymers, while moderate thermal stability was confirmed in these polymers: $T_{\mathrm{d} 5} 355^{\circ} \mathrm{C}$ for $\operatorname{poly1-H}, 235^{\circ} \mathrm{C}$, for $\operatorname{poly}(R)-1-$
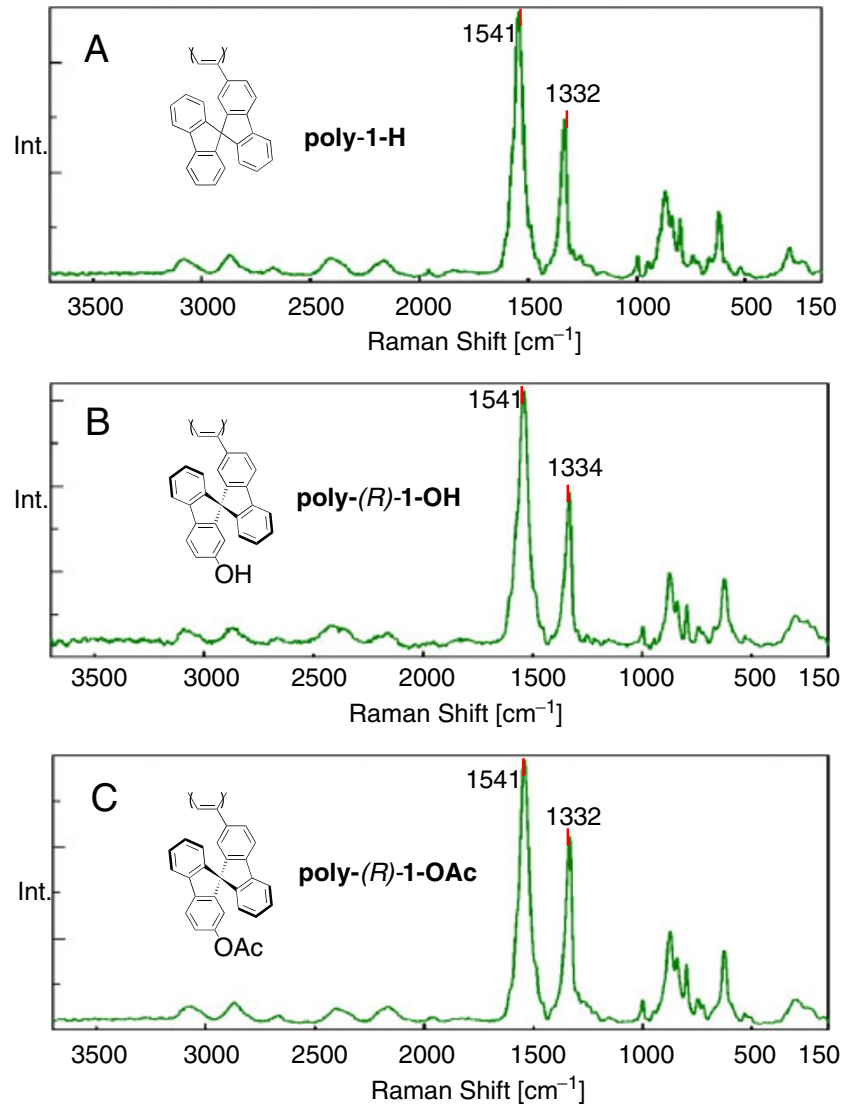

Figure 2. Raman spectra of (A) poly1-H, (B) poly $(R)-1-0 H$, and (C) poly $(R)$-1-OAc $\left(\mathrm{Ar}^{+}\right.$laser $\left.532 \mathrm{~nm}\right)$.

$\mathbf{O H}$, and $232{ }^{\circ} \mathrm{C}$ for $\operatorname{poly}(R)-1-O A c$. The optically inactive polymer poly1-H showed fairly higher thermal stability than the optically active ones, though the reason is not clear at present time.

Solubility of $\operatorname{poly}(R)-\mathbf{1 - O H}$ was rather low in not only aprotic less polar solvents such as toluene and chloroform but also protic and/or polar solvents such as DMSO, $\mathrm{MeOH}$, and $\mathrm{CH}_{3} \mathrm{CN}$ : only soluble in THF, probably because of the presence of polar $\mathrm{OH}$ group on the side chain. Both poly1-H and poly $(R)$-1-OAc had high solubility toward typical organic solvents such as toluene, chloroform, and THF. 

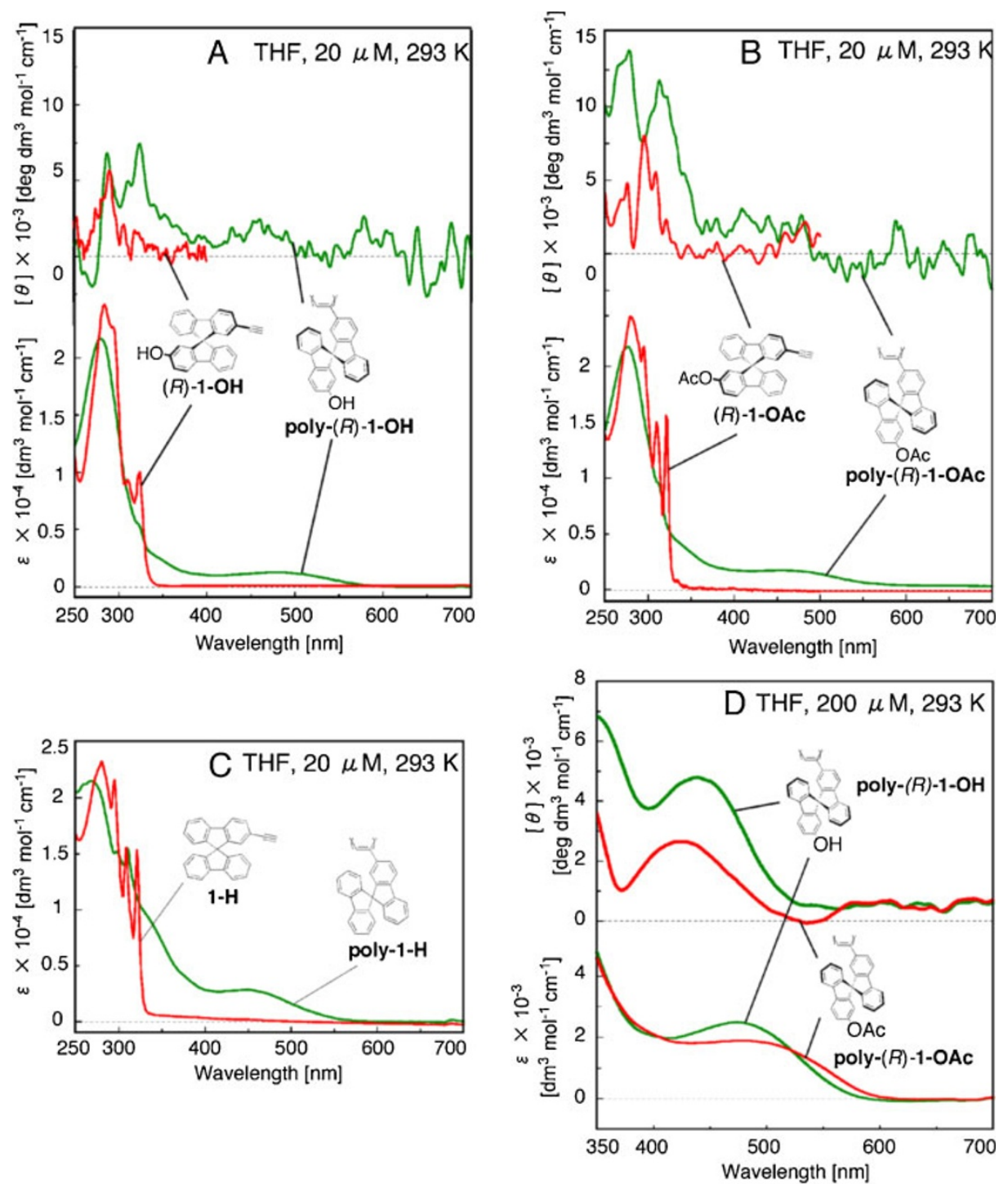

Figure 3. A-C: UV-vis and CD spectra of the ethynyl monomers 1 and polyacetylenes poly 1 (THF, $293 \mathrm{~K}, 20 \mu \mathrm{M}, 250-700 \mathrm{~nm}$ ) and $\mathbf{D}$ for $\mathrm{CD}$ spectra of poly $(R)$ 1-OH and poly $(R)-1-\mathrm{OAc}(\mathrm{THF}, 293 \mathrm{~K}, 200 \mu \mathrm{M}, 350-700 \mathrm{~nm}$ ).

\section{Structure of Polyacetylenes}

${ }^{1} \mathrm{H}$ NMR spectra of all polymers had only very broadened signals throughout the charts which were not indicative of the polymer structures at all. The IR spectral data of the polymers supported the formation of substituted polyacetylenes by the absorptions at $3437(\mathrm{O}-\mathrm{H})$ and $1757(\mathrm{C}=\mathrm{O})$. To get the information on the main chain structures, Raman spectra of the polymers were measured. Figure 2 reveals the Raman spectra of poly1 where there are two typical strong absorptions at 1541 and $1333 \mathrm{~cm}^{-1}$ corresponding to the cis-transoidal structure of the polymer main chain. ${ }^{19,20}$ The clear spectral chracteristics undoubtedly indicated the complete cis-transoidal conformations of these three polyacetylenes, which are in good accordance with the reported results with the polymerization catalyst $[\mathrm{Rh}(\mathrm{nbd}) \mathrm{Cl}]_{2} .{ }^{19}$

Inspection of the specific rotation data of poly $(R)-\mathbf{1 - O H}$ and $\operatorname{poly}(R)-1-O A c$ in Table I clearly indicates that the polymers take some higher order or regular structures in solution, judging from the rotation values bigger than those of the corresponding monomers. Meanwhile, the Cotton effect was observed with the two optically active polymers in the CD spectra (Figure 3). Although the Cotton effects of the two monomers around $270 \mathrm{~nm}$ were very weak in both cases, those for the polymers were sufficiently bigger than them, strongly suggesting the generation of some secondary structures in polymer state. In particular, the positive Cotton effect around the UV absorption region of the conjugated polyacetylene main chain $(480 \mathrm{~nm})$ suggests the main chain chirality produced by the polymerization. The most conceivable structure is helix for these polyacetylenes, i.e., the formation of excess amount of polyacetylene having one-handed helical sense.

Uv-vis spectra of poly1 showed clearly absorptions at 450$500 \mathrm{~nm}$ region based on the interchromophore interaction of the side chain groups, which was not observed in the correspond- 
(A)
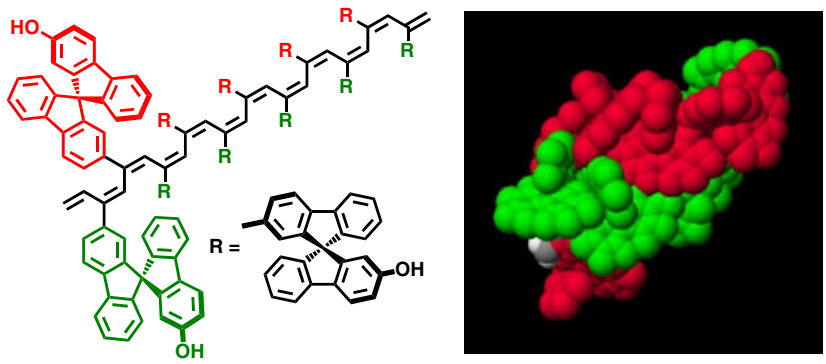

(B)
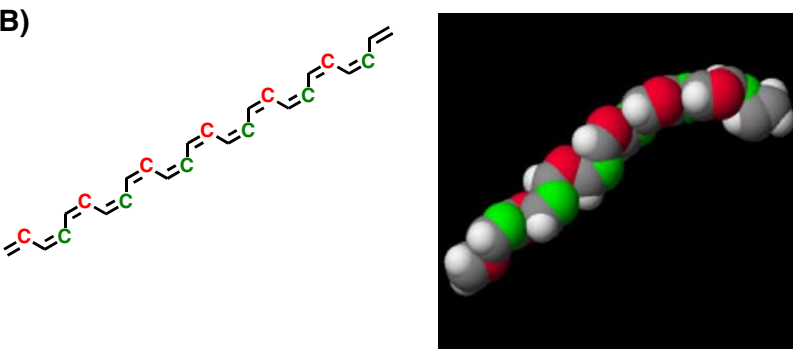

Figure 4. Energy-minimized structure of model 12mer of $\operatorname{poly}(R)-1-\mathbf{O H}$ calculated by MM2. (A) Two-color printed figure of the opposite pendant groups and (B) the opposite carbon atoms arranged along the cis-transoidal main chain.

ing monomers 1 (Figure 3, A-C). As shown in CD spectra (Figure 3), each monomer showed weak Cotton effect while the corresponding polymer had stronger Cotton effect at 250$400 \mathrm{~nm}$ region. Clear positive Cotton effect was also confirmed around $450 \mathrm{~nm}$ corresponding to the main chain absorption regions of the optically active polymers. The results indicate the induction of helical chirality in both $\operatorname{poly}(R)-\mathbf{1 - O H}$ and poly $(R)$-1-OAc. There was little temperature dependency on $\mathrm{CD}$ intensity and Cotton effect in both polymers, suggesting the stable helical structures. Large steric interaction between the bulky side chain groups of the spirobifluorenes in addition to the rigid main chain seems to extraordinarily stabilize the helical structure of the polymers, so that no temperature dependency was observed.

Figure 4 displays the MM2-simulated structure of the $12 \mathrm{mer}$ model for $\operatorname{poly}(R)-\mathbf{1 - O H}$, in which the helical conformation was calculated. The bulky pendant groups forced to be arranged along the helical main chain by the strong steric repulsion between them, as shown in Figure 4(A). The helix from monomer $(R)-\mathbf{1 - O H}$ has a right-handed 16-1 helical structure (Figure 4(B)).

\section{CONCLUSION}

We described in the present study the synthesis, property, and structure of a few polyacetylenes having the pendent optically active spirobifluorene moiety as a $C_{2}$ chiral group. The experimental results suggested the formation of optically active polymers which took the cis-transoidal main chain conformation. Although the detailed structures of the polymers are not clear at present time, it would be easy to conceive that they can take some helical structures induced by the introduc- tion of a group with molecular chirality in the side chain. The simulated structures of the polymers were the right-handed helical structures (16-1 helix in the case of $\operatorname{poly}(\boldsymbol{R})$-1-OH), like those reported so far. ${ }^{19,22}$

Received: April 25, 2008

Accepted: June 3, 2008

Published: July 24, 2008

\section{REFERENCES}

1. a) C. Yamamoto and Y. Okamoto. Bull. Chem. Soc. Jpn., 77, 227 (2004).

b) S. Habaue and Y. Okamoto, Chem. Rec., 1, 46 (2001).

c) T. Nakano and Y. Okamoto, Chem. Rev., 101, 4013 (2001).

d) Y. Okamoto, K. Suzuki, K. Ohta, K. Hatada, and H. Yuki, J. Am. Chem. Soc., 101, 4763 (1979).

2. a) K. Ute, K. Hirose, H. Kashimoto, K. Hatada, and O. Vogl, J. Am. Chem. Soc., 113, 6305 (1991).

b) L. S. Corley and O. Vogl, Polym. Bull., 3, 211 (1980).

3. a) K. Onitsuka, T. Mori, M. Yamamoto, F. Takei, and S. Takahashi, Macromolecules, 39, 7224 (2006).

b) J. J. L. M. Cornelissen, W. S. Graswinckel, A. E. Rowan, N. A. J. M. Sommerdijk, and R. J. M. Nolte, J. Polym. Sci., Part A: Polym. Chem., 41, 1725 (2003).

c) T. J. Deming and B. M. Novak, J. Am. Chem. Soc., 115, 9101 (1993).

d) P. C. J. Kamer, R. J. M. Nolte, W. J. Drenth, H. H.-M. Nijis, and J. A. Kanters, J. Mol. Catal., 49, 21 (1988).

4. a) B. T. Muellers, J. W. Park, M. S. Brookhart, and M. M. Green, Macromolecules, 34, 572 (2001).

b) M. M. Green, J. Park, T. Sato, A. Teramoto, S. Lifson, R. L. B. Selinger, and J. V. Selinger, Angew. Chem., Int. Ed., 38, 3138 (1999). c) M. M. Green, C. Andreola, B. Muñoz, M. P. Reidy, and K. Zero, J. Am. Chem. Soc., 110, 4063 (1988).

d) M. Goodman and S. Chen, Macromolecules, 3, 398 (1970).

5. a) A. Saxena, R. Rai, S. Y. Kim, M. Fujiki, M. Naito, K. Okoshi, and G. Kwak, J. Polym. Sci., Part A: Polym. Chem., 44, 5060 (2006).

b) T. Sato, K. Terao, A. Teramoto, and M. Fujiki, Polymer, 44, 5477 (2003).

c) M. Fujiki, J. Am. Chem. Soc., 116, 6017 (1994).

d) M. Fujiki, J. Am. Chem. Soc., 116, 11976 (1994).

6. a) J. Tabei, M. Shiotsuki, F. Sanda, and T. Masuda, Macromolecules, 38, 5860 (2005).

b) J. Tabei, R. Nomura, M. Shiotsuki, F. Sanda, and T. Masuda, Macromol. Chem. Phys., 206, 323 (2005).

c) J. Deng, J. Tabei, M. Shiotsuki, F. Sanda, and T. Masuda, Macromolecules, 37, 7156 (2004).

d) J. Deng, J. Tabei, M. Shiotsuki, F. Sanda, and T. Masuda, Macromolecules, 37, 5149 (2004).

e) J. Tabei, R. Nomura, and T. Masuda, Macromolecules, 35, 5405 (2002).

f) R. Nomura, J. Tabei, and T. Masuda, J. Am. Chem. Soc., 123, 8430 (2001).

7. a) H. Nakako, R. Nomura, and T. Masuda, Macromolecules, 34, 1496 (2001).

b) H. Nakako, Y. Mayahara, R. Nomura, M. Tabata, and T. Masuda, Macromolecules, 33, 3978 (2000).

c) R. Nomura, H. Fukushima, H. Nakako, and T. Masuda, J. Am. Chem. Soc., 122, 8830 (2000).

d) H. Nakako, R. Nomura, M. Tabata, and T. Masuda, Macromolecules, 32, 2861 (1999).

e) E. Yashima, Y. Maeda, and Y. Okamoto, Polym. J., 31, 1033 (1999).

f) M. Shiotsuki, W. Zhang, and T. Masuda, Polym. J., 39, 690 (2007). 
8. a) H. Onouchi, T. Hasegawa, D. Kashiwagi, H. Ishiguro, K. Maeda, and E. Yashima, Macromolecules, 38, 8625 (2005).

b) K. Morino, M. Oobo, and E. Yashima, Macromolecules, 38, 3461 (2005).

c) H. Zhao, F. Sanda, and T. Masuda, Polymer, 46, 2841 (2005).

d) F. Sanda, K. Terada, and T. Masuda, Macromolecules, 38, 8149 (2005).

e) J. W. Y. Lam and B. Z. Tang, Acc. Chem. Res., 38, 745 (2005).

f) G. Gao, F. Sanda, and T. Masuda, Macromolecules, 36, 3932 (2003).

g) B. S. Li, K. K. L. Cheuk, L. S. Ling, J. W. Chen, X. D. Xiao, C. L. Bai, and B. Z. Tang, Macromolecules, 36, 77 (2003).

h) Y. Hu, R. Liu, F. Sanda, and T. Masuda, Polym. J., 40, (2008).

9. a) J. Kadokawa, K. Tawa, M. Suenaga, Y. Kaneko, and M. Tabata, J. Macromol. Sci., Part A: Pure Appl. Chem., 43, 1179 (2006).

b) I. Otsuka, R. Sakai, T. Satoh, R. Kakuchi, H. Kaga, and T. Kakuchi, J. Polym. Sci., Part A: Polym. Chem., 43, 5855 (2005).

c) K. Matuura, S. Furuno, and K. Kobayashi, Chem. Lett., 847 (1998).

10. a) T. Aoki, K.-i. Shinohara, T. Kaneko, and E. Oikawa, Macromolecules, 29, 4192 (1996).

b) T. Aoki and T. Kaneko, Polym. J., 37, 717 (2005).

11. Aoki have mentioned the synthesis of polyacetylene having a pendant optically active binaphtyl group, although the details are not referred. Polym. Prepr. Jpn. 1998, 47, 2373.

12. a) T. Takata, Y, Furusho, K. Murakawa, T. Endo, H. Matsuoka, T. Hirasa, J. Matsuo, and M. Sisido, J. Am. Chem. Soc., 120, 4530
(1998).

b) T. Takata, K. Murakawa, and Y. Furusho, Polym. J. 31, 1051 (1999).

13. a) T. Maeda, T. Takeuchi, Y. Furusho, and T. Takata, J. Polym. Sci., Part A: Polym. Chem., 42, 4693 (2004).

b) T. Maeda, Y. Furusho, and T. Takata, Chirality, 14, 587 (2002).

14. T. Hachiya, N. Kitamura, H. Mori, and T. Yasuda. Eur. Pat. Appl., A2, 1298117 (2003).

15. S. J. Havens and P. M. Hergenrother, J. Org. Chem., 50, 1763 (1985).

16. H. N. Cho, S. H. Jung, and S. J. Park, U.S. Patent 2005176915, A1 (2005).

17. G. Haas and V. Prelog, Helv. Chim. Acta, 52, 1202 (1969).

18. F. Toda and K. Tanaka, J. Org. Chem. 53, 3607 (1988).

19. a) J. Sedláček and J. Vohlídal, Collect. Czech. Chem. Commun., 68, 1745 (2003).

b) M. Tabata, T. Sone, and Y. Sadahiro, Macromol. Chem. Phys., 200, 265 (1999).

c) Y. Kishimoto, M. Itou, T. Miyake, T. Ikariya, and R. Noyori, Macromolecules, 28, 6662 (1995).

d) A. Furlani, C. Napoletano, M. V. Russo, A. Camus, and N. Marsich, J. Polym. Sci., Part A: Polym. Chem., 27, 75 (1989).

20. T. Harada, M. Tasumi, and H. Shirakawa, Chem. Lett. 1411 (1978).

21. V. Percec, M. Obata, J. G. Rudick, B. B. De, M. Glodde, T. K. Bera, S. N. Magonov, V. S. K. Balagurusamy, and P. A. Heiney, J. Polym. Sci., Part A: Polym. Chem., 40, 3509 (2002). 